\title{
EFFECT OF INTRAVENOUS INFUSIONS OF ETHANOL UPON ESTIMATED HEPATIC BLOOD FLOW IN MAN ${ }^{1}$
}

\author{
By ALBERT I. MENDELOFF \\ (From the Nutrition Rescarch Laboratory, Department of Preventive Medicine, Washington \\ Uniz'ersity School of Medicine, and the Barnes Hospital, St. Louis, Mo.)
}

(Submitted for publication April 15, 1954 ; accepted June 16, 1954)

During the course of studies concerning the utilization by the human liver of parenteral feeding solutions containing ethanol, it was observed that these infusions resulted consistently in changes in the estimated hepatic blood flow. The amount of ethanol infused into these human subjects produced blood ethanol concentrations far below those known to be intoxicating (1), and lower than those levels reported to achieve some degree of postoperative sedation (2). Since even massive ethanol dosage is reportedly without effect on mammalian hemodynamics (3), it seemed unlikely that the changes in estimated hepatic blood flow observed here were due to gross changes in the circulation. This report demonstrates that the infusion of small amounts of ethanol in saline into unanesthetized adult human subjects produces consistently significant increases in estimated hepatic blood flow, most probably as a result of a specific decrease in splanchnic peripheral resistance.

\section{METHODS AND PROCEDURES}

The subjects were young adult males with either gastric or duodenal ulcers, but without evidence of primary liver disease, malnutrition, anemia, or dehydration. On the morning of the study each was fasting (except for subject M. S., who had eaten a piece of toast) at $7: 30$ a.m., when he received a subcutaneous injection of 60 mg. sodium phenobarbital. At 8 a.m. each was subjected to hepatic vein catheterization (4). Following a priming dose of $150 \mathrm{mg}$. of the dye, an intravenous infusion of 0.85 per cent sodium chloride solution containing enough bromsulfalein (BSP) to produce an infusion rate of approximately $3 \mathrm{mg}$. per min. per square meter of surface area was begun. The actual amount of this "control solution" infused varied from 5 to $9 \mathrm{ml}$. per minute among the five subjects, but was maintained constant in each subject. After approximately 30 minutes, without changing the tubing or drip control, a second bottle was substituted for the first; this second bottle

1 This work was carried out under Contract No. DA49-007-MD-410 between the Office of the Surgeon General, Department of the Army, Washington, D. C., and the Washington University School of Medicine. contained the same amount of BSP dissolved in the salt solution, to which absolute ethanol had been added in an amount sufficient to give a final concentration of 5 per cent $w / v$. This "alcohol solution" was then allowed to run in at approximately the same rate as had the "control solution" for periods varying from 50 to 80 minutes.

Blood samples were taken from peripheral veins and the right hepatic venous tree in all cases. In certain subjects arterial samples were also obtained from the radial or femoral arteries. These blood samples were analyzed in the following ways :

BSP concentrations were determined in serum by the method of Bradley, Ingelfinger, Bradley, and Curry (4) utilizing a Coleman, Jr. spectrophotometer; total reducing sugars were analyzed for by the method of Somogyi as modified by Nelson (5); lactic acid was determined by the method of Summerson and Barker as modified by LePage (6), and pyruvic acid by the method of Liu as modified by Friedemann and Haugen (7). Plasma pepsinogen was calculated in terms of micrograms tyrosine released per $\mathrm{ml}$. of whole blood according to the technique of Mirsky, Futterman, Kaplan, and Broh-Kahn (8). The methods developed by Stotz, Westerfeld and Berg were used to determine the whole blood content of acetaldehyde (9) and of ethanol (10).

Two additional studies were carried out. In the first of these BSP in saline solution was administered to one subject for 90 minutes; at thirty-minute intervals the infusion rate was changed, so that he received the solution at rates of 20,9 , and $8 \mathrm{ml}$. per minute, respectively, for each thirty-minute period, representing $11,4.95$, and 4.4 mg. BSP per minute. These three rates constitute extremes beyond the range of variation in volume of solution administered per minute during the studies with the ethanol solution, and serve to demonstrate the effect upon EHBF of volume of solution and amount of BSP administered. In the second study, an infusion of a saline solution was administered to a healthy adult male at a rate of $8 \mathrm{ml}$. per minute for 20 minutes; at this point ethanol in saline was administered at exactly the same rate for $\mathbf{4 5}$ minutes, at the end of which time the original solution was again infused at the same rate. Cardiac output by the dye dilution method (11) was measured twice during the first saline period, three times during the ethanol period, and once during the second saline period. Results were expressed as the cardiac index-cardiac output in liters per minute divided by the surface area of each subject. Arterial and peripheral venous blood levels of ethanol were determined during the ethanol period. 
RESULTS

The data relating specifically to estimated hepatic blood flow may be seen in Table I. Here it will be noted that in every one of these five subjects there was a significant increase in estimated hepatic blood flow during the infusion of ethanol in saline. At the same time, the peripheral venous concentrations of BSP were either unchanged or slightly decreased, indicating that no impairment in the ability of the liver to remove dye had occurred, if one presupposes that extrahepatic removal of dye under these circumstances remained constant.

Data pertaining to the oxidation of ethanol, production or utilization of lactic acid and of pyruvic acid, and to the changes in blood glucose and plasma pepsinogen are summarized in Table II. The glucose levels were reasonably constant, as were the values for plasma pepsinogen; this constancy may be interpreted to mean that none of the subjects became unduly anxious during the carrying out of the procedures. The blood ethanol levels were in all subjects well below the concentrations known to be associated with symptoms of in- toxication, and with one exception were below the levels found by Rice, Orr, and Enquist necessary to provide postoperative patients with a sedative and analgesic effect ( 70 to $100 \mathrm{mg}$. per 100 ml.) (2). All subjects showed an uptake of ethanol by the splanchnic system, presumably by the liver, although in E. R. this was much less than in the other four men, who demonstrate uptakes varying from 15 to 50 per cent of the peripheral concentrations. The changes in lactic acid concentrations evident in these studies showed no unidirectional features; the blood levels of this metabolite were generally elevated during the alcohol period, but there were marked variations in the concentrations in the hepatic vein blood. Pyruvate levels also varied considerably, tending to fall during the alcohol period, with lower concentrations consistently found in hepatic as compared to peripheral blood.

The study summarized in Table III was designed to demonstrate that the infusion rates employed in these studies do not change the estimated hepatic blood flow as the result of fluid added to the circulation. The experimental results summarized in Table IV show clearly that ethanol

TABLE I

Data used for calculating estimated hepatic blood flow (EHBF) in five subjects receiving i.v. saline in "control period" and $i .{ }^{\prime}$. saline +5 per cent ethanol in "alcohol period" *

\begin{tabular}{|c|c|c|c|c|c|c|c|c|c|c|c|}
\hline \multirow[b]{2}{*}{ Subject } & & \multirow{2}{*}{$\begin{array}{l}\text { Minutes } \\
\text { after } \\
\text { infusion } \\
\text { began }\end{array}$} & \multicolumn{3}{|c|}{$\underset{m g . / 100 \mathrm{ml} . \text { serum }}{\mathrm{BSP}}$} & \multirow{2}{*}{$\begin{array}{c}\text { BSP } \\
\text { infused } \\
\text { mg./min. }\end{array}$} & \multirow{2}{*}{$\begin{array}{c}\text { BSP } \\
\text { removed } \\
m g . / m i n .\end{array}$} & \multirow{2}{*}{$\frac{100 R}{P-H}$} & \multirow{2}{*}{$\frac{1}{1-\text { Hct. }}$} & \multirow{2}{*}{$\underset{m l . / m i n}{\mathrm{EHBF}}$} & \multirow{2}{*}{$\begin{array}{l}\text { Per cent } \\
\text { change } \\
\text { from } \\
\text { control }\end{array}$} \\
\hline & & & $\mathrm{P}$ & $\mathrm{H}$ & $\mathrm{P}-\mathrm{H}$ & & & & & & \\
\hline L.S. & $\begin{array}{r}\text { Control } \\
\text { period } \\
\text { Alcohol } \\
\text { period }\end{array}$ & $\begin{array}{l}20 \\
28 \\
30 \\
60\end{array}$ & $\begin{array}{l}1.10 \\
1.15 \\
0.85 \\
0.88\end{array}$ & $\begin{array}{l}0.35 \\
0.40 \\
0.45 \\
0.45\end{array}$ & $\begin{array}{l}0.75 \\
0.75 \\
0.40 \\
0.43\end{array}$ & $\begin{array}{l}7.3 \\
7.3 \\
5.5 \\
5.5\end{array}$ & $\begin{array}{l}7.2 \\
5.4\end{array}$ & $\begin{array}{r}960 \\
1,280\end{array}$ & $\begin{array}{l}1.85 \\
1.85\end{array}$ & $\begin{array}{l}1,770 \\
2,380\end{array}$ & 34.5 \\
\hline J. C. & $\begin{array}{r}\text { Control } \\
\text { period } \\
\text { Alcohol } \\
\text { period }\end{array}$ & $\begin{array}{l}16 \\
21 \\
30 \\
48\end{array}$ & $\begin{array}{l}3.45 \\
3.35 \\
3.8 \\
4.2\end{array}$ & $\begin{array}{l}2.30 \\
2.35 \\
3.00 \\
3.50\end{array}$ & $\begin{array}{l}1.15 \\
1.00 \\
0.80 \\
0.70\end{array}$ & $\begin{array}{l}6.55 \\
6.55 \\
6.62 \\
6.62\end{array}$ & $\begin{array}{l}6.05 \\
6.00\end{array}$ & $\begin{array}{l}568 \\
860\end{array}$ & $\begin{array}{l}1.57 \\
1.57\end{array}$ & $\begin{array}{r}895 \\
1,340\end{array}$ & 49.7 \\
\hline E. T. & $\begin{array}{r}\text { Control } \\
\text { period } \\
\text { Alcohol } \\
\text { period }\end{array}$ & $\begin{array}{l}20 \\
25 \\
23 \\
48\end{array}$ & $\begin{array}{l}1.05 \\
1.05 \\
1.20 \\
1.30\end{array}$ & $\begin{array}{l}0.45 \\
0.45 \\
0.75 \\
0.80\end{array}$ & $\begin{array}{l}0.60 \\
0.60 \\
0.45 \\
0.50\end{array}$ & $\begin{array}{l}7.35 \\
7.35 \\
7.02 \\
7.02\end{array}$ & $\begin{array}{l}6.85 \\
6.91\end{array}$ & $\begin{array}{l}1,142 \\
1,458\end{array}$ & $\begin{array}{l}1.72 \\
1.72\end{array}$ & $\begin{array}{l}1,960 \\
2,500\end{array}$ & 27.6 \\
\hline M. S. & $\begin{array}{r}\text { Control } \\
\text { period } \\
\text { Alcohol } \\
\text { period }\end{array}$ & $\begin{array}{l}24 \\
29 \\
30 \\
55\end{array}$ & $\begin{array}{l}1.10 \\
1.05 \\
0.70 \\
0.56\end{array}$ & $\begin{array}{l}0.20 \\
0.30 \\
0.20 \\
0.25\end{array}$ & $\begin{array}{l}0.90 \\
0.75 \\
0.50 \\
0.31\end{array}$ & $\begin{array}{l}8.7 \\
8.7 \\
4.34 \\
4.34\end{array}$ & $\begin{array}{l}9.0 \\
5.42\end{array}$ & $\begin{array}{l}1,100 \\
1,750\end{array}$ & $\begin{array}{l}1.72 \\
1.72\end{array}$ & $\begin{array}{l}1,890 \\
3,000\end{array}$ & 58.0 \\
\hline E. R. & $\begin{array}{r}\text { Control } \\
\text { period } \\
\text { Alcohol } \\
\text { period }\end{array}$ & $\begin{array}{l}33 \\
38 \\
19 \\
39\end{array}$ & $\begin{array}{l}1.75 \\
1.75 \\
1.15 \\
1.10\end{array}$ & $\begin{array}{l}1.05 \\
1.15 \\
0.80 \\
0.70\end{array}$ & $\begin{array}{l}0.70 \\
0.60 \\
0.35 \\
0.45\end{array}$ & $\begin{array}{l}6.0 \\
6.0 \\
5.4 \\
5.4\end{array}$ & $\begin{array}{l}6.0 \\
5.44\end{array}$ & $\begin{array}{r}924 \\
1,430\end{array}$ & $\begin{array}{l}1.76 \\
1.76\end{array}$ & $\begin{array}{l}1,620 \\
2,510\end{array}$ & 55.0 \\
\hline
\end{tabular}

* $\mathrm{P}$-peripheral venous blood; $\mathrm{H}$-hepatic venous blood; $\mathrm{R}-\mathrm{BSP}$ removed, mg. per min.; Hct-hematocrit. 
TABLE II

Combined data for infusions of saline and of saline-ethanol mixtures in five subjects *

\begin{tabular}{|c|c|c|c|c|c|c|c|c|c|c|c|c|c|}
\hline \multirow[b]{2}{*}{ Patient } & \multicolumn{5}{|c|}{ Control period } & \multicolumn{8}{|c|}{ Alcohol period } \\
\hline & $\begin{array}{c}\text { EHBF } \\
\text { min./ } \\
\text { min. }\end{array}$ & $\begin{array}{c}\text { Glu- } \\
\text { cose } \\
m g . / \\
100 \mathrm{ml} .\end{array}$ & $\begin{array}{c}\text { Lac- } \\
\text { tate } \\
m g . / \\
100 \mathrm{ml} .\end{array}$ & $\begin{array}{c}\text { Pyru- } \\
\text { vate } \\
\text { mg. } \\
100 \mathrm{ml} .\end{array}$ & $\begin{array}{l}\text { Pepsin- } \\
\text { ogen } \\
m c g . \\
t y r . / m l .\end{array}$ & 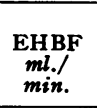 & & $\begin{array}{l}\text { Glu- } \\
\text { cose } \\
\text { mg./ } \\
00 \mathrm{ml} .\end{array}$ & $\begin{array}{c}\text { Lac- } \\
\text { tate } \\
m g . / \\
100 \mathrm{ml} .\end{array}$ & $\begin{array}{c}\text { Pyru- } \\
\text { vate } \\
\text { mg./ } \\
100 \mathrm{ml} .\end{array}$ & $\begin{array}{l}\text { Pepsin- } \\
\text { ogen } \\
\text { mcg. } \\
\text { tyr./ml. }\end{array}$ & $\begin{array}{c}\text { Alco- } \\
\text { hol } \\
m g . / \\
100 \mathrm{ml} .\end{array}$ & $\begin{array}{c}\text { Acetal- } \\
\text { dehyde } \\
m g . / \\
100 \mathrm{ml} .\end{array}$ \\
\hline \multirow{2}{*}{$\begin{array}{l}\text { L. S. } \\
42 \text { yrs. } \\
\text { Gastric } \\
\text { ulcer }\end{array}$} & \multirow{2}{*}{1,770} & P 100 & 17.9 & 2.0 & - & \multirow{2}{*}{2,380} & $\mathrm{P}$ & 94 & 26.0 & 2.8 & - & 28.0 & 0.13 \\
\hline & & H 116 & 16.9 & 1.9 & - & & $\mathrm{H}$ & 98 & 50.0 & 1.6 & - & 14.0 & 0.04 \\
\hline \multirow{2}{*}{$\begin{array}{l}\text { J. C. } \\
48 \text { yrs. } \\
\text { Duodenal } \\
\text { ulcer }\end{array}$} & \multirow{2}{*}{895} & & 6.6 & 1.8 & 0.61 & \multirow{2}{*}{1,340} & $\mathbf{P}$ & 83 & 10.4 & 1.9 & 0.59 & 81.5 & 0.42 \\
\hline & & H 120 & 5.6 & 1.5 & - & & $\mathbf{H}$ & 130 & 16.9 & 1.6 & - & 57.8 & 0.41 \\
\hline \multirow{2}{*}{$\begin{array}{l}\text { E. T. } \\
31 \text { yrs. } \\
\text { Duodenal } \\
\text { ulcer }\end{array}$} & \multirow{2}{*}{1,960} & P $\quad 88$ & 17.4 & 2.0 & 0.67 & \multirow{2}{*}{2,500} & $\mathbf{P}$ & 88 & 30.2 & 1.4 & 0.69 & 47.5 & 0.24 \\
\hline & & H 100 & 23.3 & 1.6 & 0.67 & & $\mathbf{H}$ & 103 & 12.9 & 1.4 & 0.61 & 39.0 & 0.19 \\
\hline \multirow{2}{*}{$\begin{array}{l}\text { E. R. } \\
39 \text { yrs. } \\
\text { Duodenal } \\
\text { ulcer }\end{array}$} & \multirow{2}{*}{1,620} & & 17.2 & - & 0.64 & \multirow{2}{*}{2,510} & $\mathbf{P}$ & 89 & 21.3 & 2.0 & 0.68 & 25.5 & 0.32 \\
\hline & & H 100 & 21.3 & - & 0.62 & & $\mathbf{H}$ & 92 & 11.1 & 1.8 & 0.68 & 24.0 & 0.26 \\
\hline \multirow{2}{*}{$\begin{array}{l}\text { M. S. } † \\
31 \text { yrs. } \\
\text { Duodenal } \\
\text { ulcer }\end{array}$} & \multirow{2}{*}{1,890} & P 121 & 10.1 & 2.7 & 0.45 & \multirow{2}{*}{3,000} & $\mathbf{P}$ & 99 & 28.6 & 1.7 & 0.36 & 45.0 & 0.05 \\
\hline & & H 129 & 14.8 & 3.3 & 0.22 & & $\mathbf{H}$ & 127 & 29.8 & 1.3 & 0.35 & 38.0 & 0.04 \\
\hline
\end{tabular}

* All calculations represent concentrations of substances per units of whole blood. P-peripheral venous blood; H-hepatic venous blood; EHBF-estimated hepatic blood flow; tyr.-tyrosine.

† Note: Patient M. S. had eaten a slice of toast.

infusions sufficient to maintain blood levels of this magnitude do not increase cardiac output, as measured by the dye dilution method (11); if any change occurs, cardiac output seems to be decreased by these levels of ethanol in the blood.

\section{DISCUSSION}

In the voluminous literature pertaining to the biochemical and physiological effects of ethanol on the mammalian body, only the recent study of Smythe, Heinemann, and Bradley (3) devotes attention to a comprehensive analysis of its action upon the hepatic blood flow. Their experiments were carried out on anesthetized dogs to whom ethanol was administered by gavage; the results may be summarized as showing no significant alteration in cardiac output, hepatic blood flow, or renal blood flow. The results of the present study are at variance with those reported by Bradley in that they show clearcut increases in the estimated hepatic blood flow produced by constant intravenous infusions of ethanol, at blood concentrations well below those necessary to produce symptoms of sedation or intoxication, or signs of peripheral vasodilation or of sweating. Not one of the subjects was able to recognize the taste, odor, or any other characteristics of ethanol during the course of the experiments. There were no changes in

TABLE III

Control study in one subject, utilizing saline infusion at three different rates, each rate being maintained for 30 minutes

\begin{tabular}{|c|c|c|c|c|c|c|c|c|c|c|c|c|}
\hline \multirow{2}{*}{$\begin{array}{l}\text { Minutes } \\
\text { after } \\
\text { infusion } \\
\text { began }\end{array}$} & \multicolumn{2}{|c|}{ Infusion rate } & \multicolumn{3}{|c|}{$\stackrel{\text { BSP }}{\text { mg. per } 100 \text { ml. serum }}$} & \multirow{2}{*}{$\underset{m l . / m i n}{\mathrm{EHBF}}$} & \multicolumn{2}{|c|}{$\begin{array}{l}\text { Glucose } \\
\text { mg./100 ml. } \\
\text { blood }\end{array}$} & \multicolumn{2}{|c|}{$\begin{array}{c}\text { Lactate } \\
\text { mg./100 ml. } \\
\text { blood }\end{array}$} & \multicolumn{2}{|c|}{$\begin{array}{l}\text { Pyruvate } \\
\text { mg./100 ml. } \\
\text { blood }\end{array}$} \\
\hline & $\begin{array}{l}\text { Volume } \\
\text { ml./min. }\end{array}$ & $\begin{array}{l}\text { BSP } \\
m g . / m i n .\end{array}$ & $\mathbf{P}$ & $\mathrm{H}$ & $\overline{P-H}$ & & $P$ & H & $\mathbf{P}$ & $\mathrm{H}$ & $\mathbf{P}$ & $\overline{\mathrm{H}}$ \\
\hline $\begin{array}{l}24 \\
54 \\
84\end{array}$ & $\begin{array}{r}20.0 \\
9.0 \\
8.0\end{array}$ & $\begin{array}{c}11.0 \\
4.95 \\
4.4\end{array}$ & $\begin{array}{l}2.5 \\
1.4 \\
1.35\end{array}$ & $\begin{array}{l}0.55 \\
0.65 \\
0.55\end{array}$ & $\begin{array}{l}1.95 \\
0.75 \\
0.80\end{array}$ & $\begin{array}{r}960 \\
1,050 \\
940\end{array}$ & $\begin{array}{l}99 \\
98 \\
93\end{array}$ & $\begin{array}{l}113 \\
112 \\
108\end{array}$ & $\begin{array}{l}16.4 \\
10.5 \\
14.9\end{array}$ & $\begin{array}{r}8.7 \\
13.1 \\
8.9\end{array}$ & $\begin{array}{l}1.88 \\
1.68 \\
1.98\end{array}$ & $\begin{array}{l}1.88 \\
1.52 \\
1.66\end{array}$ \\
\hline
\end{tabular}


TABLE IV

Cardiac indices in one subject during infusion of saline, saline +5 per cent ethanol, and saline again, at a constant infusion rate of $8 \mathrm{ml}$. per minute

\begin{tabular}{|c|c|c|c|c|c|c|}
\hline \multirow[b]{2}{*}{ Minutes after infusion began } & \multicolumn{2}{|c|}{ Saline infusion No. 1} & \multicolumn{3}{|c|}{ Ethanol infusion } & \multirow{2}{*}{$\frac{\text { Saline inf usion No. } 2}{12 \mathrm{~min} .}$} \\
\hline & 15 min. & $18 \mathrm{~min}$. & $16 \mathrm{~min}$. & $30 \mathrm{~min}$. & $43 \mathrm{~min}$. & \\
\hline Cardiac index & 5.2 & 5.4 & 4.7 & 5.10 & 4.7 & 5.3 \\
\hline Ethanol mg. per $100 \mathrm{ml}$. blood & - & - & (ante & $\begin{array}{l}\text { lial arte } \\
\text { bital ve }\end{array}$ & $\begin{array}{r}-45 \\
-42\end{array}$ & - \\
\hline
\end{tabular}

blood pressure. The fact that these increases in hepatic blood flow occurred in the absence of elevations of the peripheral $\mathrm{BSP}$ concentration must mean that the liver suffered no impairment of its ability to remove the dye during the alcohol period; there is no reason to suspect that extrahepatic removal of BSP was increased by the ethanol, although this possibility cannot be disproved. The many determinations of hepatic blood flow in this and in other laboratories do not support the possibility that infusions of 5 to $9 \mathrm{ml}$. of saline per minute per se increase hepatic blood flow, and there exists no evidence that ethanol itself causes an increase in cardiac output, of which the hepatic blood flow might partake proportionately. The simplest explanation would be that low peripheral blood levels of ethanol in unanesthetized man are associated with a decreased peripheral resistance in the splanchnic bed, giving rise to a significant increase in estimated hepatic blood flow.

The plasma pepsinogen levels were determined principally because in this laboratory it has been found that psychological stress rapidly elevates these values, in normal subjects as well as in those with peptic ulcers; these elevations are accompanied by changes in the output of gastric pepsin, but are reflected much more slowly in the urinary uropepsin excretion (12). Since these subjects all had peptic ulcer disease, it was felt that plasma pepsinogen values might be an excellent measure of the stress effect of the experiment. The fact that plasma pepsinogen failed to show significant increases during these studies, plus the relative stability of the blood glucose values, can be interpreted to mean that anxiety provoked by, or arising in the course of these experiments was of negligible significance.

It has been reported (13) that intravenous ethanol increases gastric secretion in normal subjects, although the increases described were not of great magnitude. In the studies reported here, there is no evidence that these blood levels of ethanol are associated with any elevation of the plasma pepsinogen concentrations over the control values. As has been pointed out by Mirsky, Futterman, Kaplan, and Broh-Kahn (8) the pepsinogen values of plasma are not necessarily influenced by secretagogues, but seem to reflect the interdigestive or continuous phase of gastric secretory activity.

Comparisons of ethanol concentrations in arterial and in peripheral venous blood in these studies and in the experiments of others (14) demonstrate a minimal peripheral disappearance of ethanol. All but one subject showed a significant hepatic uptake of ethanol; acetaldehyde was detected in both peripheral and hepatic venous blood, but the concentrations measured must represent only a small part of the acetaldehyde formed from these blood concentrations of ethanol. The present study provides no information as to the fate of the acetaldehyde formed; however, these data are in agreement with current theory as to conversion of ethanol via alcohol dehydrogenase to acetaldehyde and reduced DPN.

\section{CONCLUSIONS}

1. In each of five male subjects with peptic ulcer disease, the intravenous infusions of an ethanolsaline mixture maintaining blood ethanol levels at 25 to $81 \mathrm{mg}$. per $100 \mathrm{ml}$. caused a significant increase in estimated hepatic blood flow over values determined when saline solutions alone are administered at the same rate.

2. This increase in estimated hepatic blood flow resulting from ethanol cannot be explained on the basis of increased cardiac output, but seems best described as due to a lowering of the peripheral resistance of the splanchnic bed. 
3. Metabolic data relating to the overall hepatic uptake of ethanol and production of acetaldehyde were consistent with present concepts of the intermediary metabolism of ethanol.

\section{ACKNOWLEDGMENT}

The author wishes to acknowledge with thanks the technical assistance of Mrs. Mary Koch and Mrs. Jeannine Ruch.

\section{REFERENCES}

1. Emerson, H., ed., Alcohol and Man, New York, Macmillan Co., 1932.

2. Rice, C. O., Orr, B., and Enquist, I., Parenteral nutrition in the surgical patient as provided from glucose, amino acids, and alcohol. Ann. Surg., 1950, 131, 289.

3. Smythe, C. McC., Heinemann, H. O., and Bradley, S. E., Estimated hepatic blood flow in the dog: effect of ethyl alcohol on it, renal blood flow, cardiac output and arterial pressure. Am. J. Physiol., 1953, 172, 737.

4. Bradley, S. E., Ingelfinger, F. J., Bradley, G. P., and Curry, J. J., The estimation of hepatic blood flow in man. J. Clin. Invest., 1945, 24, 890.

5. Nelson, N., A photometric adaptation of the Somogyi method for the determination of glucose. J. Biol. Chem., 1944, 153, 375.

6. LePage, C. A., in Umbreit, W. W., Burris, B. H., and
Stauffer, I. F., Manometric techniques and related methods for the study of tissue metabolism, Minneapolis, Burgess Publishing Co., 1945, p. 104.

7. Friedemann, T. E., and Haugen, G. E., Pyruvic acid. II. The determination of keto acids in blood and urine. J. Biol. Chem., 1943, 147, 415.

8. Mirsky, I. A., Futterman, P., Kaplan, S., and BrohKahn, R. H., Blood plasma pepsinogen. I. The source, properties, and assay of the proteolytic activity of plasma at acid reactions. J. Lab. \& Clin. Med., 1952, 40, 17.

9. Stotz, E., A colorimetric determination of acetaldehyde in blood. J. Biol. Chem., 1943, 148, 585.

10. Westerfeld, W. W., Stotz, E., and Berg, R. L., The role of pyruvate in the metabolism of ethyl alcohol. J. Biol. Chem., 1942, 144, 657.

11. Friedlich, A., Heimbecker, R. O., and Bing, R. J., A device for continuous recording of concentration of Evans blue dye in whole blood and its application to determination of cardiac output. J. Applied Physiol., 1950, 3, 12.

12. Mendeloff, A. I., and Graham, D. T., Unpublished data.

13. Newman, H. W., and Mehrtens, H. G., Effect of intravenous infusion of ethyl alcohol on gastric secretion in man. Proc. Soc. Exper. Biol. \& Med., 1932, 30, 145

14. Mirsky, I. A., and Nelson, N., The influence of the pancreas and the liver on the oxidation of ethyl alcohol. Am. J. Physiol., 1939, 127, 308. 